\title{
Multiresidue Determination of Herbicides in Environmental Waters from Primavera do Leste Region (Middle West of Brazil) by SPE-GC-NPD
}

\author{
Eliana F. G. C. Dores, ${ }^{*, a, c}$ Sandro Navickiene, ${ }^{b}$ Marcelo L. F. Cunha, ${ }^{a}$ Leandro Carbo, ${ }^{a}$ \\ Maria Lúcia Ribeiro ${ }^{c}$ and Ermelinda M. De-Lamonica-Freire ${ }^{d}$ \\ ${ }^{a}$ Departamento de Química, Universidade Federal de Mato Grosso, 78060-900 Cuiabá-MT, Brazil \\ ${ }^{b}$ Departamento de Química, Universidade Federal de Sergipe, 49100-000 São Cristóvão-SE, Brazil \\ ${ }^{c}$ Instituto de Química, Universidade Estadual Paulista, 14801-970 Araraquara-SP, Brazil \\ ${ }^{d}$ Centro Universitário de Várzea Grande (UNIVAG), 78118-000 Várzea Grande-MT, Brazil
}

Foi desenvolvido um estudo sobre a presença dos herbicidas simazina, metribuzim, metolacloro, trifluralina, atrazina e seus metabólitos desisopropilatrazina (DIA) e desetilatrazina (DEA) em água superficial e subterrânea da região de Primavera do Leste, Mato Grosso, Brasil. O procedimento analítico baseou-se na extração em fase sólida com cartuchos descartáveis Sep-Pak $\mathrm{C}_{18}$ e eluição com acetato de etila. Os níveis de resíduos foram determinados por cromatografia a gás com detector de nitrogênio e fósforo. Para a maior parte dos pesticidas, a recuperação média nos diferentes níveis de fortificação foi $>70 \%$ com estimativa do desvio padrão relativo $<19 \%$. As recuperações observadas para o DIA e a trifluralina foram $25 \%$ e $56 \%$, respectivamente. As baixas recuperações foram atribuídas à retenção incompleta do DIA e à forte retenção no sorvente e alta volatilidade da trifluralina. Os limites de detecção variaram de 0,023 a $0,088 \mu \mathrm{g} \mathrm{L}{ }^{-1}$. Este método foi aplicado na análise de 5 amostras de águas superficiais e 28 de águas subterrâneas, em pontos usados para abastecimento de água para consumo humano, coletadas em Primavera do Leste, Mato Grosso. O nível mais elevado encontrado nas amostras de água foi $1,732 \mu \mathrm{g} \mathrm{L}^{-1}$ de metolacloro enquanto o herbicida encontrado com maior frequiência foi o metribuzim.

A study on the presence of herbicides, namely simazine, metribuzin, metolachlor, trifluralin, atrazine and two metabolites, deisopropylatrazine (DIA) and deethylatrazine (DEA), was performed in ground and surface waters from Primavera do Leste region, Mato Grosso state (Middle West of Brazil). The analytical procedure was based on solid-phase extraction (SPE) with Sep-Pak $\mathrm{C}_{18}$ disposable cartridges and ethyl acetate for elution solvent. Residue levels were determined by gas chromatography with nitrogen-phosphorus detection. For most of the pesticides average recoveries at different fortification levels were $>70 \%$ with relative standard deviation $<19 \%$. The recoveries of DIA and trifluralin in water were $25 \%$ and $56 \%$, respectively, which were attributed to the incomplete retention of DIA and strong retention on the sorbing material and high volatility of trifluralin. Detection limits ranged from 0.023 to $0.088 \mu \mathrm{g} \mathrm{L}^{-1}$. This method was applied for the analysis of 5 superficial water samples and 28 groundwater samples, in places used for human consumption without previous treatment, collected in Primavera do Leste, Mato Grosso, Brazil. Results indicated that the highest level of contamination in a water sample was $1.732 \mu \mathrm{g} \mathrm{L}^{-1}$ for metolachlor, while metribuzin was the most frequently detected herbicide with maximum concentration of $0.351 \mu \mathrm{g} \mathrm{L}^{-1}$.

Keywords: solid-phase extraction, water, herbicides, pesticides, GC-NPD

\section{Introduction}

The Primavera do Leste region (Mato Grosso state, Middle West of Brazil) is an area with a high agricultural

*e-mail: eliana@cpd.ufmt.br production, that has expanded greatly since its start 30 years ago. As consequence of the monoculture conditions under which soybean, cotton, rice, maize and bean are grown, they are susceptible to pest attack throughout the year. Therefore, herbicides are extensively used in horticultural crops to control weeds that may produce yield reduction. However, 
after their application, pesticide residues may remain in the crops, soil and natural water and constitute a health risk because of their toxicity. A literature review revealed data on pesticide contamination of aquatic environment in the tropical and subtropical areas..$^{1-6}$ In Brazil, although research on pesticide leaching from agricultural areas to groundwater was initiated years ago, the knowledge of the levels of contamination of groundwater is still very scarce in the regions of the Middle West and North of Brazil. Unfortunately, there are few methods for determining pesticide residues in Brazilian environmental compartments. Among them, atrazine, simazine and amethrin were studied in a waterworks of São Paulo state. ${ }^{7}$ Trifluralin, endosulfan, $\lambda$-cyhalothrin, dicofol, captan, methyl parathion, chlorothalonil, and chlorpyrifos were determined in groundwater and surface water in Guaíra region, São Paulo state. ${ }^{8}$ In another study, 29 pesticides and 3 metabolites were determined in surface water of northeastern area of Pantanal region and glifosate and its main metabolite were studied in water from a rice-growing area. ${ }^{9-10}$

The present work reports the optimization of an SPE method for simultaneous determination of simazine, metribuzin, metolachlor, trifluralin, atrazine and two of its metabolites, deisopropylatrazine (DIA) and deethylatrazine (DEA), in water by means of gas chromatography using nitrogen-phosphorus detection. The pesticides selected are the most frequently used in this agricultural area. The method was successfully applied to determine the levels of these herbicides in water samples taken from different water sources located in Primavera do Leste region.

\section{Experimental}

Reagents

Ethyl acetate, acetone and methanol (Mallinckrodt Baker Inc., Paris, KY, USA) of nanograde purity were used. The pesticide standards of deisopropylatrazine (96.5\%), deethylatrazine (95.5\%), trifluralin (99.2\%), atrazine $(98.4 \%)$, simazine $(99.2 \%)$, metribuzin $(99.5 \%)$ and metolachlor $(95.0 \%)$ were purchased from Dr. Ehrenstorfer (Augsburg, Germany). The individual stock solutions of the analytes were prepared by diluting $1.0 \mathrm{mg}$ of the standard in $10.0 \mathrm{~mL}$ of ethyl acetate to obtain a concentration of $100 \mu \mathrm{g} \mathrm{mL}^{-1}$. The working standard solutions were prepared by diluting the stock solutions as required. The deionized water was purified with a Milli-Q water purification system (Millipore, Bedford, MA, USA). Hydrochloric acid of analytical grade was from Merck (Darmstadt, Germany). Sodium chloride of residue analysis grade was purchased from
Merck (Darmstadt, Germany). Sep-Pak $\mathrm{C}_{18}$-bonded silica commercial cartridges (500 and $1000 \mathrm{mg}$ ) were purchased from Waters (Mildford, MA, USA).

\section{Apparatus}

A Hewlett-Packard 6890 gas chromatograph equipped with a split/splitless injector and a nitrogen-phosphorus detection system was employed. A DB-5 fused-silica capillary column $(30 \mathrm{~m} \times 0.32 \mathrm{~mm}$ i.d., $0.25 \mu \mathrm{m}$; J \& W Scientific, Folsom, CA, USA) was used, with nitrogen (purity 99.999\%) as carrier and make up gas at flow-rates of $1 \mathrm{~mL} \mathrm{~min}^{-1}$ and 7

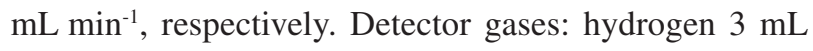
$\mathrm{min}^{-1}$ and air $60 \mathrm{~mL} \mathrm{~min}^{-1}$. The injector temperature was set at $240{ }^{\circ} \mathrm{C}$ and the detector temperature was $300{ }^{\circ} \mathrm{C}$. The oven temperature was programmed as follows: $70^{\circ} \mathrm{C}$ for 1 min, increased to $150^{\circ} \mathrm{C}$ at $20^{\circ} \mathrm{C} \mathrm{min}^{-1}$, then to $180^{\circ} \mathrm{C}$ at $3{ }^{\circ} \mathrm{C} \mathrm{min}^{-1}$ and followed by final ramp to $240{ }^{\circ} \mathrm{C}$ at $10^{\circ} \mathrm{C}$ $\mathrm{min}^{-1}$ (hold for $1 \mathrm{~min}$ ). The data were acquired and processed by HP Chemstation software. An aliquot $(1 \mu \mathrm{L})$ of the water extracts, standards and blanks was injected in the splitless mode into the GC-NPD system.

\section{Sample collection and preparation}

In the beginning of the rain season in this tropical area (December 1998), thirty-three water samples were collected from different water sources in agricultural zone located in Primavera do Leste region (Middle West of Brazil between $1532^{\prime} \mathrm{S}$ to $1534^{\prime} \mathrm{S}$ and $5417^{\prime} \mathrm{W}$ to $541^{\prime} \mathrm{W}$ ) in $1 \mathrm{~L}$ amber glass bottles pretreated with acetone and methanol. After being filled with water, the bottles were sealed with Teflonlined screw caps and transported on the same day to the laboratory in refrigerated conditions. In the laboratory, before the solid-phase extraction, the water samples were filtered in a $0.45 \mu \mathrm{m}$ cellulose nitrate membrane filter, the $\mathrm{pH}$ was adjusted between 6.5 and 7.5 with $1 \mathrm{~mol} \mathrm{~L}^{-1} \mathrm{HCl}$ and the $\mathrm{NaCl}$ was added to ionic strength correction $(17.5 \%, \mathrm{~m} / \mathrm{v})$. The sampling sites were irrigation and drinking water wells (23), waterholes (5), dam (2) and Cabeceira dos Bois river (3). Numbers between parenthesis represent number of sampling points at each sampling sites.

\section{Extraction procedure}

A Sep-Pak Vac $\mathrm{C}_{18}$ cartridge was placed on top of a vacuum block and it was conditioned with $10 \mathrm{~mL}$ of methanol followed by $10 \mathrm{~mL}$ of water, before applying the sample. An analytical aliquot of $500 \mathrm{~mL}$ water was transferred to the cartridge at a flow-rate of $c a$. $5 \mathrm{~mL} \mathrm{~min}^{-1}$. The herbicides were eluted with $2 \times 10 \mathrm{~mL}$ 
of ethyl acetate at a flow-rate of ca. $1 \mathrm{~mL} \mathrm{~min}^{-1}$. The combined fractions were concentrated in a rotary evaporator and the residue was redissolved in $1 \mathrm{~mL}$ of ethyl acetate for GC-NPD analysis.

\section{Recovery studies}

Recovery studies were carried out with tap water samples free of residual pesticides, which were spiked with standard mixture at different concentration levels. At each fortification level, six replicates were analyzed. Quantification was performed by external calibration using certified standards. Sample analyses were run in duplicate and most relative standard deviations (RSDs) of less than $19 \%$ were achieved. The extraction procedure described above was followed. The limits of detection and quantification were determined based on the criteria established by Thier and Zeumer. ${ }^{11}$ The limit of detection (LOD) was calculated using equation 1 .

$$
\mathrm{LOD}=\frac{2 \cdot \mathrm{t}_{(\mathrm{f} ; 95)} \cdot \mathrm{s}_{\mathrm{comb}}}{\mathrm{S}}
$$

Where $\mathrm{s}_{\text {comb }}$ is the combined standard deviation; $\mathrm{S}$ is the sensitivity; $\mathrm{t}_{(\mathrm{f} ; 95)}$ is the unilateral $\mathrm{t}$ of Student, with $\mathrm{f}$ degrees of freedom and confidence level of $95 \%$; $\mathrm{f}=\mathrm{d}-1$ and $\mathrm{d}$ is the number of replicates at each fortification level.

The sensitivity was determined as a measure of the proportionality of the instrumental response and the analyte concentration.

The combined standard deviation $\left(\mathrm{s}_{\text {comb }}\right)$ was calculated using equation (2).

$\mathrm{s}_{\text {comb }}=\sqrt{\frac{(\mathrm{m}-1) \mathrm{s}_{\mathrm{A}}^{2}+(\mathrm{n}-1) \mathrm{s}_{\mathrm{B}}^{2}}{\mathrm{~m}+\mathrm{n}-2}}$

where $s_{A}$ is the standard deviation of the measured concentrations at the lowest fortification level used in the recovery experiment; $m$ is the number of replicates at the lowest fortification level; $s_{B}$ is the standard deviation of the responses of the blank determinations and $n$ is the number of blank determinations.

The limit of quantification (LOQ) was the lowest fortification level where mean recovery between 70 and $120 \%$ and relative standard deviation less than $20 \%$ were obtained.

\section{Results and Discussion}

\section{GC-NPD conditions}

In a first approach, the GC-NPD conditions were optimized to separate the herbicides studied. For that, different temperature programs were tested in order to resolve the pesticides of the standard mixture. The representative chromatograms of the standard mixture, fortified water sample and water control sample are shown in Figure 1. No interfering peaks were present. The total running time was $20 \mathrm{~min}$.

\section{Optimization of solid-phase extraction}

The proposed SPE method was based on previous procedures established by Junker-Buchheit and Witzenbacher ${ }^{12}$ and Eisert et al. ${ }^{13}$ for the determination of pesticide residues in water. Different parameters related to the extraction process were evaluated. Table 1 shows the experiments realized to the optimization of the SPE procedure in order to improve the recovery. These experiments were performed in triplicate. The extraction carried out by the method A showed lower recovery for DIA and trifluralin with high relative standard deviation (RSD) values for both pesticides (Table 2). The low recovery for trifluralin was due to the effect of irreversible adsorption taking place on the $\mathrm{C}_{18}$ surface and high volatility, while some uncontrollable loss of DIA occurred during the SPE procedure, once it is not well retained by the sorbent. In method $\mathrm{B}$, considering the same amount of $\mathrm{C}_{18}$ material, the influence of the sample volume was assayed. The average recoveries for DIA and trifluralin were improved from $19 \%$ to $60 \%$ and $20 \%$ to $59 \%$, respectively. No significant differences in DIA recoveries were noted from water samples analyzed by methods B, C and $\mathrm{D}$. The eluent volume used for subsequent study was set at $20 \mathrm{~mL}$. In method $\mathrm{E}$, the effect of addition of salt was also evaluated with water sample salted with $\mathrm{NaCl}$. Salt increases the ionic strength of the water sample and enhances the extraction from water because it reduces analyte solubility. Greater areas for DIA were registered when $87.5 \mathrm{~g}$ of $\mathrm{NaCl}$ were added. Further experiments were performed by the addition of $\mathrm{NaCl}(17.5 \%, \mathrm{~m} / \mathrm{v})$.

Table 1. Analytical parameters assayed for the optimization of the SPE method

\begin{tabular}{|c|c|c|c|c|c|}
\hline Method & $\begin{array}{l}\text { Sample } \\
\text { volume / } \\
(\mathrm{mL})\end{array}$ & $\begin{array}{l}\text { Sorbent } \\
\text { amount / } \\
(\mathrm{mg})\end{array}$ & $\begin{array}{l}\text { Cartridge } \\
\text { conditioning }\end{array}$ & $\begin{array}{c}\mathrm{NaCl} \\
\text { addition }\end{array}$ & $\begin{array}{c}\text { Eluent } \\
\text { volume / } \\
(\mathrm{mL})\end{array}$ \\
\hline A & 500 & 500 & $\begin{array}{l}5 \mathrm{~mL} \mathrm{H} \mathrm{H}_{2}+ \\
5 \mathrm{~mL} \mathrm{MeOH}\end{array}$ & no & $2 \times 5$ \\
\hline B & 250 & 500 & $\begin{array}{l}5 \mathrm{~mL} \mathrm{H}_{2} \mathrm{O}+ \\
5 \mathrm{~mL} \mathrm{MeOH}\end{array}$ & no & $2 \times 5$ \\
\hline C & 200 & 500 & $\begin{array}{l}5 \mathrm{~mL} \mathrm{H} \mathrm{H}_{2}+ \\
5 \mathrm{~mL} \mathrm{MeOH} \\
10 \mathrm{~mL} \mathrm{MeOH}\end{array}$ & no & $2 \times 8$ \\
\hline D & 500 & 1000 & $\begin{array}{l}10 \mathrm{~mL} \mathrm{H}_{2} \mathrm{O}+ \\
10 \mathrm{~mL} \mathrm{MeOH}\end{array}$ & no & $2 \times 10$ \\
\hline $\mathrm{E}$ & 500 & 1000 & $\begin{array}{l}10 \mathrm{~mL} \mathrm{H}_{2} \mathrm{O}+ \\
10 \mathrm{~mL} \mathrm{MeOH}\end{array}$ & yes & $2 \times 10$ \\
\hline
\end{tabular}



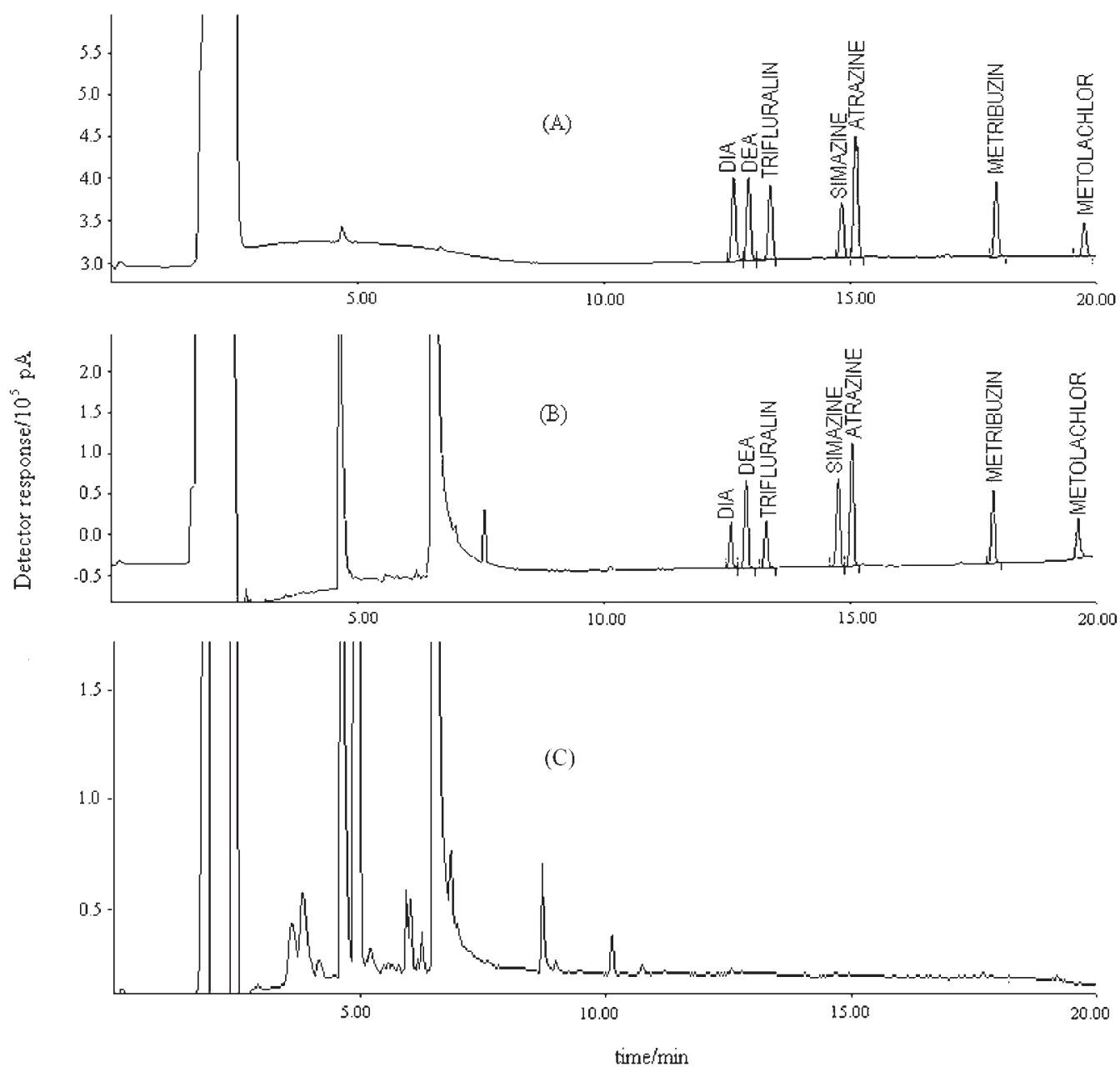

Figure 1. GC-NPD chromatograms of (A) standard mixture containing atrazine $\left(0.314 \mu \mathrm{g} \mathrm{mL}^{-1}\right)$, DIA $\left.\left(0.208 \mu \mathrm{g} \mathrm{mL} L^{-1}\right), \mathrm{DEA}^{(0.188 \mu \mathrm{g} \mathrm{mL}} \mathrm{m}^{-1}\right)$, simazine $\left(0.200 \mu \mathrm{g} \mathrm{mL}^{-1}\right)$, metribuzin $\left(0.424 \mu \mathrm{g} \mathrm{mL}^{-1}\right)$, metolachlor $\left(0.824 \mu \mathrm{g} \mathrm{mL}^{-1}\right)$, trifluralin $\left(0.408 \mu \mathrm{g} \mathrm{mL}^{-1}\right)$; (B) water sample fortified with atrazine $\left(0.107 \mu \mathrm{g} \mathrm{L}^{-1}\right)$, DIA $\left(0.104 \mu \mathrm{g} \mathrm{L}{ }^{-1}\right)$, DEA $\left(0.094 \mu \mathrm{g} \mathrm{L}^{-1}\right)$, simazine $\left(0.100 \mu \mathrm{g} \mathrm{L}^{-1}\right)$, metribuzin $\left(0.212 \mu \mathrm{g} \mathrm{L}^{-1}\right)$, metolachlor $\left(0.412 \mu \mathrm{g} \mathrm{L}^{-1}\right)$ and trifluralin $\left(0.204 \mu \mathrm{g} \mathrm{L}^{-1}\right)$; (C) water control sample. For chromatographic conditions, see text.

Table 2. Effect on the herbicide recovery of different methods

\begin{tabular}{lcccccccccc}
\hline Herbicide & $\begin{array}{c}\mathrm{A} \\
\mathrm{Rec}^{\mathrm{a}}\end{array}$ & $\mathrm{RSD} /(\%)$ & $\mathrm{B}$ & $\mathrm{Rec}$ & $\mathrm{RSD} /(\%)$ & $\begin{array}{c}\mathrm{C} \\
\mathrm{Rec}\end{array}$ & $\mathrm{RSD} /(\%)$ & $\begin{array}{c}\mathrm{D} \\
\mathrm{Rec}\end{array}$ & $\begin{array}{c}\mathrm{E} \\
\mathrm{RSD} /(\%)\end{array}$ & $\begin{array}{c}\text { Rec } \\
\text { RSD / }(\%)\end{array}$ \\
\hline DIA & 19 & 79 & 60 & 30 & 57 & 27 & 54 & 14 & 83 & 14 \\
DEA & 82 & 5.7 & 108 & 6.6 & 106 & 7 & 104 & 10 & 87 & 19 \\
Atrazine & 97 & 5.9 & 101 & 7.9 & 91 & 3.5 & 100 & 5.3 & 94 & 14 \\
Simazine & 93 & 9.9 & 91 & 4.7 & 86 & 5.4 & 93 & 6.2 & 92 & 11 \\
Metribuzin & 87 & 8.3 & 82 & 6.6 & 96 & 16 & 94 & 19 & 75 & 10 \\
Trifluralin & 20 & 63 & 59 & 4.8 & 45 & 19 & 82 & 11 & 67 & 14 \\
Metolachlor & 98 & 5.9 & 102 & 1.7 & 92 & 9.2 & 109 & 5.5 & 91 & 3.0 \\
\hline
\end{tabular}

${ }^{\mathrm{a}} \operatorname{Rec}=$ Recovery $(\mathrm{n}=3)$; RSD = Relative Standard Deviation

Based on these results, the method E was selected to determine the herbicides studied in spiking samples of tap water at different levels for each pesticide. Each recovery analysis was repeated 6 times. The results of the average recoveries ranged from $72 \%$ to $110 \%$, with
RSD values of $2 \%$ to $19 \%$, as can be seen in Table 3, except for DIA and trifluralin, which gave lower recoveries $25 \%$ and $56 \%$, respectively. Lower recoveries of DIA and trifluralin have been reported in the literature. ${ }^{9,14-16}$ 
Table 3. Recovery efficiency of herbicides from fortified water by GCNPD analysis $(* n=6)$

\begin{tabular}{|c|c|c|c|c|c|}
\hline \multirow[t]{2}{*}{ Herbicide } & \multirow{2}{*}{$\begin{array}{c}\text { Fortification } \\
\text { level / }\left(\mu g \mathrm{~L}^{-1}\right)\end{array}$} & \multicolumn{3}{|c|}{ Recovery / (\%) } & \multirow{2}{*}{$\begin{array}{l}\mathrm{RSD} / \\
(\%)\end{array}$} \\
\hline & & Range & Average $^{*}$ & SD & \\
\hline \multicolumn{6}{|l|}{ DIA } \\
\hline & 0.104 & $66-104$ & 83 & 11.6 & 14 \\
\hline & 0.402 & $34-141$ & 84 & 43.7 & 52 \\
\hline & 2.08 & $18-28$ & 25 & 4.3 & 17 \\
\hline \multicolumn{6}{|l|}{ DEA } \\
\hline & 0.094 & $56-104$ & 87 & 16.5 & 19 \\
\hline & 0.376 & $97-119$ & 109 & 8.7 & 8 \\
\hline & 1.88 & $76-90$ & 85 & 6.4 & 8 \\
\hline \multirow[t]{4}{*}{ Atrazine } & 0.054 & $83-140$ & 110 & 19.8 & 18 \\
\hline & 0.107 & $74-110$ & 92 & 10 & 11 \\
\hline & 0.428 & $98-112$ & 104 & 4.4 & 4 \\
\hline & 2.14 & $94-103$ & 98 & 3.7 & 4 \\
\hline \multirow[t]{4}{*}{ Simazine } & 0.050 & $82-118$ & 104 & 11.4 & 11 \\
\hline & 0.100 & 71-108 & 94 & 13.1 & 14 \\
\hline & 0.400 & $97-123$ & 110 & 10.2 & 9 \\
\hline & 2.00 & $96-101$ & 99 & 2.4 & 2 \\
\hline \multirow[t]{4}{*}{ Metribuzin } & 0.106 & $70-115$ & 92 & 13.8 & 15 \\
\hline & 0.212 & $61-103$ & 75 & 14.5 & 19 \\
\hline & 0.848 & 81-104 & 91 & 9.1 & 10 \\
\hline & 4.24 & $61-79$ & 72 & 7.9 & 11 \\
\hline \multirow[t]{4}{*}{ Trifluralin } & 0.102 & $54-96$ & 75 & 12.8 & 17 \\
\hline & 0.204 & $54-82$ & 67 & 9.4 & 14 \\
\hline & 0.816 & $48-63$ & 56 & 5.5 & 10 \\
\hline & 4.08 & $46-69$ & 57 & 9.1 & 16 \\
\hline \multirow[t]{4}{*}{ Metolachlor } & 0.206 & $73-106$ & 95 & 11.4 & 12 \\
\hline & 0.412 & $87-96$ & 91 & 2.7 & 3 \\
\hline & 1.648 & $90-103$ & 98 & 4.1 & 4 \\
\hline & 8.24 & $102-107$ & 105 & 2.1 & 2 \\
\hline
\end{tabular}

Many authors have described methods for the determination of these herbicides in water using gas chromatography with nitrogen phosphorus detection or mass spectrometric detector or ultraviolet or mass selective detector through different interfaces for HPLC technique, Table 4. In terms of recovery the effectiveness of the $\mathrm{C}_{18}$ cartridge extraction procedure was compared with those obtained using SDVB resins and GCB sorbent. Therefore, the overall results are in good agreement with the one previously published by Laabs et al. ${ }^{9}$ who reported recoveries of these pesticides of $77-116 \%$ using SPE involving much larger sample volume $(1000 \mathrm{~mL})$ than in the present work.

\section{Linearity}

Under the chromatographic conditions described, good linearity and correlation coefficient were achieved for the compounds studied. Replicates $(n=3)$ of the standard pesticide mixture of different concentrations were analyzed and the detector response (peak area) was plotted against analyte concentrations. The correlations were found to be linear in the range from 0.009 to $2.060 \mu \mathrm{g} \mathrm{mL}^{-1}$.
The correlation coefficients obtained for the pesticides were higher than 0.997 as shown in Table 5 .

\section{Limits of detection (LOD) and quantification (LOQ)}

The criteria established by Thier and Zeumer to find LOD and LOQ was used in this study. ${ }^{11}$ The LOD for herbicides studied ranged from 0.023 to $0.088 \mu \mathrm{g} \mathrm{L}^{-1}$, which was calculated considering the sensitivity of the method and the standard deviation values obtained from recovery experiments at the lowest fortification level and the blank analysis. The LOQ were determined as the lowest concentration of the compounds that gave a response that could be quantified with a RSD of less than $20 \%$ and a recovery of at least $70 \%$. Consequently, the LOQ values for these compounds were between 0.050 and $0.206 \mu \mathrm{g} \mathrm{L}^{-1}$ as shown in Table 5. The detection limits obtained were in good agreement with those previously published by Panshin et al. ${ }^{17}$ and Pinto and Jardim, ${ }^{18}$ but higher than the one obtained by Laabs et al. ${ }^{9}$ and Quintana et al. ${ }^{16}$ However, the last method used other sorbent material and GC-MS technique, Table 4. On the other hand, the LOD values were lower than or equal to the maximum admissible concentration established by the European Union for the sum of all pesticides $\left(0.5 \mu \mathrm{g} \mathrm{L}^{-1}\right)$ or for an individual compound in drinking water $\left(0.1 \mu \mathrm{g} \mathrm{L} \mathrm{L}^{-1}\right)$.

\section{Application of the method}

The proposed method was applied to the determination of herbicides in water samples of different water sources located in Primavera do Leste region, Middle West of Brazil. These analyses are part of a project that aimed to study the contamination by herbicides of water used for human consumption. The results showed that out of 33 water samples, $73 \%$ had detectable herbicide residues. Figure 2 shows the chromatogram of a drinking water sample where DEA, metribuzin and metolachlor were detected. Metribuzin (16 cases) was the most frequently found pesticide in water samples, followed by simazine and DEA ( 6 cases each), metolachlor and atrazine (4 cases each) and trifluralin (2 cases). DEA was detected at high concentrations $\left(0.206 \mu \mathrm{g} \mathrm{L}^{-1}\right)$, but DIA was not found in water samples. This behaviour can be explained by considering that the removal of an ethyl chain is preferential over an isopropyl chain. Therefore DEA is more stable. Moreover, the herbicide found in most cases at concentration over the EU limits was metolachlor $\left(1.732 \mu \mathrm{g} \mathrm{L}^{-1}\right)$, which has high water 
Table 4. Comparison among different SPE methods for the determination of herbicides in water

\begin{tabular}{|c|c|c|c|c|c|c|c|c|}
\hline Method & $\begin{array}{l}\text { Sorbent }{ }^{\mathrm{a}} / \\
(\mathrm{mg})\end{array}$ & $\begin{array}{c}\text { Water / } \\
\text { Volume (mL) }\end{array}$ & $\begin{array}{l}\mathrm{pH} \text { salt } \\
\text { addition }\end{array}$ & Elution $^{\mathrm{b}}$ & Technique & $\begin{array}{l}\text { Recovery / } \\
(\%)^{c}\end{array}$ & $\begin{array}{l}\mathrm{LOD} / \\
\left(\mu \mathrm{g} \mathrm{L}^{-1}\right)\end{array}$ & $\begin{array}{l}\mathrm{LOQ} / \\
\left(\mu \mathrm{g} \mathrm{L}{ }^{-1}\right)\end{array}$ \\
\hline Laabs et al. ${ }^{9}$ & $\mathrm{C}_{18}(1250)$ & $\leq 1000$ & $\begin{array}{l}\mathrm{pH} 3 \\
20 \mathrm{~g} \mathrm{~L}^{-1} \mathrm{KCl}\end{array}$ & $\begin{array}{l}8 \mathrm{~mL} \mathrm{Hex}+ \\
12 \mathrm{~mL} \text { ethyl } \\
\text { acetate }\end{array}$ & GC/MS & $\begin{array}{l}\text { AT-103 } \\
\text { SM-108 } \\
\text { MTL-108 } \\
\text { MTR-116 } \\
\text { TRF-77 }\end{array}$ & & $\begin{array}{l}0.002 \\
0.002 \\
0.002 \\
0.002 \\
0.002\end{array}$ \\
\hline Lacorte et $a .^{14}$ & $\begin{array}{l}\text { Oasis } \\
\text { [SDVB } \\
\text { N-pyrrolidine] } \\
(60)\end{array}$ & 200 & pH 7-pH 2 & $\begin{array}{l}2.5 \mathrm{~mL} \text { ACN: } \\
\mathrm{DCM}(1: 1) \\
+3.2 \mathrm{~mL} \mathrm{DCM}\end{array}$ & GC/MS & $\begin{array}{l}\text { AT-120 (pH 7) } \\
\text { AT-143 (pH 2) } \\
\text { SM-147 (pH 7) } \\
\text { SM-149 (pH 2) } \\
\text { TRF-53 (pH 7) } \\
\text { TRF-56 (pH 2) }\end{array}$ & & \\
\hline Azevedo et al. ${ }^{15}$ & Oasis (60) & 200 & $\mathrm{pH} 4$ & $\begin{array}{l}2.5 \mathrm{~mL} \text { ACN: } \\
\mathrm{DCM}(1: 1) \\
+3.2 \mathrm{~mL} \mathrm{DCM}\end{array}$ & GC/MS & $\begin{array}{l}\text { AT-95 } \\
\text { SM-92 } \\
\text { MTL-81 } \\
\text { TRF-56 }\end{array}$ & $\begin{array}{c}0.009 \\
0.02 \\
0.01 \\
0.005\end{array}$ & \\
\hline Quintana et al. ${ }^{16}$ & $\operatorname{SDVB}(200)$ & 500 & & $\begin{array}{l}2 \times 2.5 \mathrm{~mL} \\
\text { ethyl acetate }\end{array}$ & GC/MS & $\begin{array}{l}\text { DIA-96 } \\
\text { DEA-95 } \\
\text { AT-86 } \\
\text { SM-98 } \\
\text { MTR-80 } \\
\text { MTL-102 } \\
\text { TRF-73 }\end{array}$ & $\begin{array}{l}0.008 \\
0.009 \\
0.008 \\
0.008 \\
0.035 \\
0.012 \\
0.013\end{array}$ & \\
\hline Panshin et al. ${ }^{17}$ & $\operatorname{GCB}(250)$ & $100-175$ & & $\begin{array}{l}3 \mathrm{~mL} \\
\text { ethyl acetate+ } \\
8 \mathrm{~mL} \text { DCM: } \\
\mathrm{MeOH}(70: 30)\end{array}$ & GC/MS & $\begin{array}{l}\text { AT-90-110 } \\
\text { DEA-90-107 } \\
\text { DIA-94-103 }\end{array}$ & $\begin{array}{l}0.07 \\
0.04 \\
0.03\end{array}$ & \\
\hline Pinto and Jardim ${ }^{18}$ & $\mathrm{C}_{18}(250)$ & 250 & $\begin{array}{l}\mathrm{pH}<2 \\
5 \mathrm{~g} \mathrm{NaCl}\end{array}$ & $1 \mathrm{~mL} \mathrm{MeOH}$ & HPLC/UV & $\begin{array}{l}\text { AT-76 } \\
\text { SM-77.8 }\end{array}$ & $\begin{array}{l}0.018 \\
0.012\end{array}$ & $\begin{array}{l}0.055 \\
0.037\end{array}$ \\
\hline Carabias-Martínez et al. ${ }^{19}$ & $\begin{array}{l}\text { SDVB } \\
{[\text { Lichrolut }} \\
\text { EN](200) }\end{array}$ & 100 & & $\begin{array}{l}5 \mathrm{~mL} \mathrm{MeOH} \\
+5 \mathrm{~mL} \text { ethyl } \\
\text { acetate }\end{array}$ & HPLC/DAD & $\begin{array}{l}\text { AT-95 } \\
\text { DEA-99 }\end{array}$ & $\begin{array}{l}0.02 \\
0.02\end{array}$ & \\
\hline Gferer et al. ${ }^{20}$ & $\mathrm{C}_{18}(1000)$ & & $\mathrm{pH}>7$ & $\begin{array}{l}\text { Hex:DCM: } \\
\text { ethyl acetate }\end{array}$ & GC/MS & $\begin{array}{l}\text { AT-86.9 } \\
\text { DIA-20.1 } \\
\text { DEA-56.4 } \\
\text { SM-90.3 }\end{array}$ & & $\begin{array}{l}0.001 \\
0.004 \\
0.004 \\
0.005\end{array}$ \\
\hline DiCorcia et al. ${ }^{21}$ & $\mathrm{GCB}(500)$ & $1000-4000$ & & $\begin{array}{l}1.5 \mathrm{~mL} \mathrm{MeOH} \\
+8 \mathrm{~mL} \mathrm{MeOH}: \\
\mathrm{DCM}(20: 80) \\
+50 \mathrm{mmol} \mathrm{L} \\
\text { formic acid }\end{array}$ & HPLC/ES/MS & $\begin{array}{l}\text { AT-91-99 } \\
\text { SM-89-95 } \\
\text { MTL-98-105 }\end{array}$ & $\begin{array}{l}0.0001 \\
0.0001 \\
0.0001\end{array}$ & \\
\hline Carabias-Martínez et al. ${ }^{22}$ & Oasis HLB & 500 & & $\begin{array}{l}10 \mathrm{~mL} \text { ethyl } \\
\text { acetate }\end{array}$ & HPLC/DAD & $\begin{array}{l}\text { AT-76 } \\
\text { MTR-77.8 }\end{array}$ & $\begin{array}{l}0.004 \\
0.010\end{array}$ & \\
\hline Jeannot et $a l .{ }^{23}$ & $\mathrm{C}_{18}(1000)$ & $500-1000$ & & $\begin{array}{l}2 \times 2 \mathrm{~mL} \\
\mathrm{MeOH}\end{array}$ & $\begin{array}{c}\text { HPLC/DAD } \\
\text { HPLC/MS } \\
\text { HPLC/MS/MS }\end{array}$ & $\begin{array}{l}\text { AT } \\
\text { SM } \\
\text { DIA } \\
\text { DEA }\end{array}$ & $\begin{array}{l}0.02 \\
0.02 \\
0.02 \\
0.02\end{array}$ & \\
\hline Belden et al. ${ }^{24}$ & $\mathrm{C}_{18}(1000)$ & 1000 & & $\begin{array}{l}3 \times 3 \mathrm{~mL} \\
\text { Acet:Hex (1:1) }\end{array}$ & GC/NPD & $\begin{array}{l}\text { AT-80-90 } \\
\text { SM-65-74 } \\
\text { MTL-79-91 }\end{array}$ & $\begin{array}{l}0.081 \\
0.049 \\
0.066\end{array}$ & \\
\hline Loos and Niessner ${ }^{25}$ & $\begin{array}{l}\text { LiChrolut } \\
\text { EN(200) }\end{array}$ & 200 & & $\begin{array}{l}4 \mathrm{~mL} \\
\text { MeOH:ethyl } \\
\text { acetate }(3: 2)\end{array}$ & GC/MS & $\begin{array}{l}\text { AT- } 124.8 \\
\text { DIA-99.8 } \\
\text { DEA-102.5 }\end{array}$ & & 0.005 \\
\hline \multirow[t]{2}{*}{ Tolosa et al. ${ }^{26}$} & $\operatorname{GCB}(500)$ & 1000 & $\begin{array}{l}\text { pH } 7 \\
60 \mathrm{~g} \mathrm{NaCl}\end{array}$ & $\begin{array}{l}2 \times 6 \mathrm{~mL} \\
\text { DCM }\end{array}$ & GC/NPD & $\begin{array}{l}\text { AT-89-112 } \\
\text { DIA-90-104 } \\
\text { DEA-92-103 } \\
\text { SM-93-112 }\end{array}$ & $\begin{array}{c}0.0013 \\
0.0023 \\
0.002 \\
0.0013\end{array}$ & \\
\hline & $\operatorname{SDVB}(200)$ & 1000 & $\begin{array}{l}\text { pH } 7 \\
60 \mathrm{~g} \mathrm{NaCl}\end{array}$ & $\begin{array}{l}2 \times 3 \mathrm{~mL} \\
\text { ethyl acetate }\end{array}$ & GC/NPD & $\begin{array}{l}\text { AT-80-103 } \\
\text { DIA-84-106 } \\
\text { DEA-89-100 } \\
\text { SM-83-98 }\end{array}$ & $\begin{array}{l}0.0014 \\
0.0025 \\
0.0021 \\
0.0014\end{array}$ & \\
\hline
\end{tabular}

${ }^{a} \mathrm{C}_{18}=$ octadedecylsilica, $\mathrm{SDVB}=$ styrenedivinylbenzene, $\mathrm{GCB}=$ grafitized carbon black; ${ }^{\mathrm{b}} \mathrm{DCM}=$ dichloromethane, $\mathrm{MeOH}=$ methanol, $\mathrm{ACN}=$ acetonitrile, $\mathrm{Hex}=$ hexane; ${ }^{\mathrm{c}} \mathrm{AT}=$ atrazine, $\mathrm{SM}=$ simazine, $\mathrm{MTL}=$ metolachlor, $\mathrm{MTR}=$ metribuzin, $\mathrm{TFR}=$ trifluralin. 
Table 5. Calibration data, detection limit and quantification limit of the herbicides analyzed by GC-NPD

\begin{tabular}{lccccc}
\hline Pesticide & Linear range $\left./(\mu \mathrm{g} \mathrm{mL})^{-1}\right)$ & Equation & Correlation coefficient $\left(\mathrm{r}^{2}\right)$ & LOD $\left./(\mu \mathrm{g} \mathrm{L})^{-1}\right)$ & $\left.\mathrm{LOQ}^{\prime}(\mu \mathrm{g} \mathrm{L})^{-1}\right)$ \\
\hline DIA & $0.010-0.416$ & $\mathrm{y}=-178+9468 \mathrm{x}$ & 0.9971 & 0.041 & 0.104 \\
DEA & $0.009-0.376$ & $\mathrm{y}=-143+13146 \mathrm{x}$ & 0.9990 & 0.041 & 0.078 \\
Trifluralin & $0.020-1.020$ & $\mathrm{y}=-2.19+5084 \mathrm{x}$ & 0.9997 & 0.023 & 0.102 \\
Simazine & $0.010-0.400$ & $\mathrm{y}=-44+14056 \mathrm{x}$ & 0.9996 & 0.036 & 0.050 \\
Atrazine & $0.011-0.428$ & $\mathrm{y}=-17+13727 \mathrm{x}$ & 0.9993 & 0.069 & 0.054 \\
Metribuzin & $0.021-1.060$ & $\mathrm{y}=-88+6204 \mathrm{x}$ & 0.9991 & 0.088 & 0.106 \\
Metolachlor & $0.103-2.060$ & $\mathrm{y}=-55+3338 \mathrm{x}$ & 0.9990 & & 0.206 \\
\hline
\end{tabular}

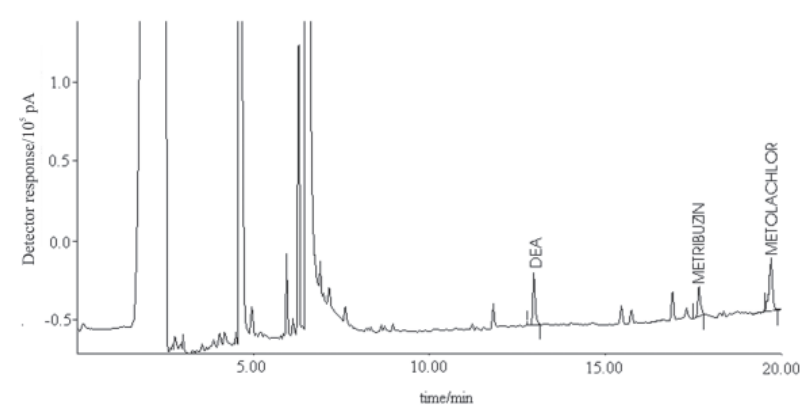

Figure 2. GC-NPD chromatogram of a drinking water well sample. For chromatographic conditions, see text.

Table 6. Occurrence of herbicides in water samples collected in the Primavera do Leste region (Middle West of Brazil) during December 1998

\begin{tabular}{|c|c|c|c|c|c|}
\hline Sampling site & $\mathrm{n}$ & Compound & freq. & $\begin{array}{c}\text { Concentration } \\
\text { min. }\end{array}$ & $\begin{array}{l}\text { / }\left(\mu \mathrm{g} \mathrm{L}^{-1}\right) \\
\max .\end{array}$ \\
\hline $\begin{array}{l}\text { drinking } \\
\text { water well }\end{array}$ & 20 & $\begin{array}{c}\text { DEA } \\
\text { atrazine } \\
\text { simazine } \\
\text { metribuzin } \\
\text { metolachlor }\end{array}$ & 14 & $\begin{array}{l}<0.041 \\
<0.036 \\
<0.023 \\
<0.069 \\
<0.088\end{array}$ & $\begin{array}{l}0.078 \\
0.063 \\
0.061 \\
0.351 \\
0.091\end{array}$ \\
\hline waterhole & 5 & $\begin{array}{l}\text { metribuzin } \\
\text { metolaclor }\end{array}$ & 4 & $\begin{array}{l}<0.069 \\
<0.088\end{array}$ & $\begin{array}{l}0.090 \\
1.732\end{array}$ \\
\hline dam & 2 & metribuzin & 1 & $<0.069$ & 0.138 \\
\hline $\begin{array}{l}\text { Cabeceira } \\
\text { dos Bois river }\end{array}$ & 3 & simazine & 2 & $<0.023$ & 0.047 \\
\hline $\begin{array}{l}\text { irrigation } \\
\text { well }\end{array}$ & 3 & $\begin{array}{c}\text { DEA } \\
\text { atrazine } \\
\text { simazine } \\
\text { metribuzin } \\
\text { trifluralin }\end{array}$ & 3 & $\begin{array}{c}<0.041 \\
0.078 \\
<0.023 \\
<0.069 \\
<0.078\end{array}$ & $\begin{array}{l}0.206 \\
0.156 \\
0.085 \\
0.129 \\
0.102\end{array}$ \\
\hline
\end{tabular}

$\mathrm{n}$ : number of water samples; min. - max.: minimum and maximum concentrations; freq.: number of positive samples.

solubility, followed by metribuzin $\left(0.351 \mu \mathrm{g} \mathrm{L}^{-1}\right)$. Table 6 contains a summary of the occurrence and concentrations of herbicides detected in samples collected during December 1998.

\section{Conclusions}

A rapid and simple SPE method for determining herbicide residues in water by GC-NPD was described. The method was adapted and validated aiming water monitoring in a region with intense agriculture activities. The low detection and quantification limits achieved with this method allow its application in the determination of herbicide levels below the MRL established by EU directive for drinking water. The SPE method was applied to determine herbicides selected in superficial and groundwater samples collected in Primavera do Leste region (Mato Grosso state, Brazil) and metribuzin was detected in many of the samples analyzed, whereas DIA was not found.

\section{Acknowledgments}

E. F. G. C. Dores thanks CNPq and FAPEMAT for financial support and S. Navickiene (project $\mathrm{n}^{\circ}$ 05.2003.01-014) thanks FAP-SE/FUNTEC and MCT/ $\mathrm{CNPq}$ for financial support and fellowship.

\section{References}

1. Castillo, L. E.; De-La-Cruz, E.; Ruepert, C.; Environ. Toxicol. Chem. 1997, 16, 41.

2. Miles, C.; Pfeuffer, R.; Arch. Environ. Contam. Toxicol. 1997, $32,337$.

3. Kammerbauer, J.; Moncada, J.; Environ. Pollut. 1998, 103, 171.

4. Botello, A. V.; Ruede-Quintana, L.; Diaz-González, G.; Toledo, A.; Bull. Environ. Contam. Toxicol. 2000, 64, 390.

5. Thurman, E. M.; Bastian, K. C.; Mollhagen, T.; Sci. Total Environ. 2000, 248, 189.

6. Zimmerman, L. R.; Thurman, E. M.; Bastian, K. C.; Sci. Total Environ. 2000, 248, 169.

7. Lanchote, V. L.; Bonato, P. S.; Cerdeira, A. L.; Santos, N. A. G.; Carvalho, D.; Gomes, M. A.; Water, Air, Soil Pollut. 2000, 118, 329.

8. Filizola, H. F.; Ferracini, V. L.; Sans, L. M. A.; Gomes, M. A. F.; Ferreira, C. J. A.; Pesq. Agrop. Bras. 2002, 37, 659.

9. Laabs, V.; Amelung, W.; Pinto, A.; Wantzen, M.; Silva, C. J.; Zech, W.; J. Environ. Qual. 2002, 31, 1636.

10. Mattos, M. L. T.; Peralba, M. C. R.; Dias, S. L. P.; Prata, F.; Camargo, L.; Pesticidas: Revista de Ecotoxicologia e Meio Ambiente 2002, 12, 145. 
11. Thier, H. P.; Zeumer, H.; Manual of Pesticide Residue Analysis, Vch: New York, 1987, vol.1.

12. Junker-Buchheit, A.; Witzenbacher, M.; J. Chromatogr., A 1996, $737,67$.

13. Eisert, R.; Levsen, K.; Wunsch, G.; Int. J. Environ. Anal. Chem. 1995, 58,103.

14. Lacorte, S.; Guiffard, I.; Fraisse, D.; Barceló, D.; Anal. Chem. 2000, 72, 1430.

15. Azevedo, D. A.; Lacorte, S.; Vinhas, T.; Viana, P.; Barceló, D.; J. Chromatogr., A 2000, 879, 13.

16. Quintana, J.; Martí, I.; Ventura, F.; J. Chromatogr., A 2001 , 938, 3 .

17. Panshin, S. Y.; Carter, D.; Baylles, E. R.; Environ. Sci. Technol. 2000, 34, 131 .

18. Pinto, G. M. F.; Jardim, I. C. S. F.; J. Chromatogr., A 2000 , $869,463$.

19. Carabias-Martínez, R.; Gonzalo, E. R.; Herrero-Hernandez, E.; San Roman, F. J. S.; Flores, M. G. P.; J. Chromatogr., A 2002, 950, 157.
20. Gfrerer, M.; Martens, D.; Gawlik, B. M.; Wenzl, T.; Zhang, A.; Quan, X.; Sun, C.; Chen, J.; Platzer, B.; Lankmayr, E.; Kettrup, A.; Chemosphere 2002, 47, 455.

21. Di Corcia, A.; Nazzari, M.; Rao, R.; Samperi, R.; Sebastiani, E.; J. Chromatogr., A 2000, 878, 87.

22. Carabias-Martínez, R.; Gonzalo, E. R.; Laespada, M. E. F.; San Roman, F. J. S.; J. Chromatogr., A 2000, 869, 471.

23. Jeannot, R.; Sabik, H.; Sauvard, E.; Genin, E.; J. Chromatogr., A 2000, 879, 51.

24. Belden, J. B.; Hofelt, C. S.; Lydy, M. J.; Arch. Environ. Contam. Toxicol. 2000, 38, 7.

25. Loos, R.; Niessner, R.; J. Chromatogr., A 1999, 835, 217.

26. Tolosa, I.; Douy, B.; Carvalho, F. P.; J. Chromatogr., A 1999 , $864,121$.

Received: August 31, 2005

Published on the web: June 20, 2006

FAPESP helped in meeting the publication costs of this article. 